\title{
Üniversite Öğrencilerinin Meslek Tercihlerini Belirleyen Faktörlere Yönelik Bir İnceleme*
}

\section{An Analysis of the Factors that Determine the Profession Preferences of University Students}

\author{
Leyla Aydemir ${ }^{\mathrm{a}, * *}$ \\ ${ }^{a}$ Dr. Öğr. Üyesi, Karadeniz Teknik Üniversitesi, Edebiyat Fakültesi, Sosyoloji Bölümü, 61080, Trabzon/Türkiye. \\ ORCID: 0000-0003-3225-2010
}

\section{MAKALE BILGİSI}

\section{Makale Geçmişi:}

Başvuru tarihi: 12 Ocak 2018

Düzeltme tarihi: 22 Ocak 2018

Kabul tarihi: 01 Şubat 2018

\section{Anahtar Kelimeler:}

Üniversite Öğrencileri

Meslek Seçimi

Bölüm Tercihi
ÖZ

Meslek seçimi kişinin yalnızca gelecekte ki kazancının, mesleki mutluluğunun değil, aynı zamanda sosyal çevresinin, yaşam kalitesinin, maddi olanaklarının vb. belirlenmesinde önemli bir etkiye sahiptir. Kişinin ileride sahip olacağı mesleği belirlemesinde üniversite eğitimi büyük önem taşımaktadır. Dolayısıyla doğru bölüm tercihi bu yolda atılan önemli bir adımdır. Bu çalışmanın amacı üniversite eğitimi almakta olan öğrencilerin bölüm seçimlerinde belirleyici rol oynamış faktörleri saptayarak bölüm seçme yeterliliklerini ve tercihlerini gerçekleştirirken sahip oldukları bilinç düzeylerini değerlendirmeyi amaçlamaktadır. Nicel araştırma yöntemlerinden anket araştırma tekniğinin kullanıldığ çalışmada elde edilen veriler IBM SPSS 23.0 programı yardımıyla analiz edilmiştir. Yapılan güvenilirlik analizi sonucunda, 891 Cronbach's Alpha değerine ulaşılmış olup, anketin güvenilir olduğu sonucuna varılmıştır. Araştırma sonunda, öğrencilerin büyük çoğunluğunun gerek kendi kararları gerekse başkalarının tavsiyeleri ile yeteneklerine uygun, iş avantajları yüksek, toplumsal saygınlığı olan meslekleri seçme eğiliminde oldukları görülmektedir. Bilinçli olarak bölüm tercihinde bulunduklarını belirten gençlerin kariyer, maddi kazanç, iş imkânı vb. etmenleri dikkate alarak hedeflerine uygun bölüm seçiminde bulundukları saptanmıştır.

\section{A B S T R A C T}

The choice of profession has an important effect not only on the future profits of the person and professional happiness, but also on the social environment, the quality of life, financial possibilities, etc. University education is of great importance in determining the future occupation of the person. So the right part is an important step taken in this way of preference. The purpose of this study is to determine the factors that played a decisive role in the university selection and to determine the competencies of department selection and to evaluate the level of consciousness they have while carrying out their preferences. In the quantitative research method, the data obtained in the study using the survey research technique was analyzed with the help of the IBM SPSS 23.0 program. As a result of the reliability analysis, 891 Cronbach's Alpha value has been reached and it is concluded that the survey is reliable. It is observed that the vast majority of students tend to choose professions with high business advantages and social prestige that are appropriate for their talents and abilities. Young people, who indicate that they have a conscious preference for the department, have chosen departments which are appropriate to their goals by taking into account some factors such as career, financial gain, job opportunity, etc.

\section{Giriş}

Meslek, belirli bir eğitim veya deneyim ile kazanılan sistemli bilgi ve becerilere dayalı, insanlara yararlı mal üretmek, hizmet vermek, bunun karşılığında para kazanmak için yapılan ve kuralları belirlenmiş iş olarak tanımlanabilir.
Bireyin mevcut meslekler arasından birisinde karar kılması ve kendisini buna hazırlamak için çaba sarf etmesi meslek seçimi olarak adlandırılır (Kuzgun, 2004).

Bireylerin kendilerini iyi şekilde ifade edebilecekleri, hayat boyu uğraşmaktan sıkılmayacakları ve kişilik yapılarına

\footnotetext{
* Bu çalışma, 18-21 Mayıs 2017 tarihlerinde Berlin'de düzenlenen Uluslararası Sosyal ve Beşeri Bilimler Konferansı'nda bildiri olarak sunulmuştur.

** Sorumlu yazar/Corresponding author.

e-posta: leylaaydemir@ktu.edu.tr
} 
uygun mesleklere yönelmeleri hem kişisel hem de toplumsal açıdan önemli kazanımlar doğurur. Kişinin kendine ve topluma daha faydalı olabilmesi için yeteneklerine uygun bir meslek seçmesi gereklidir, çünkü mesleği onun sosyal çevresini, gelir düzeyini, hayat standardını, işini severek yapmasını ve verimini etkiler. Bu nedenle, meslek seçimi bireyin hayatında önemli dönüm noktalarından bir tanesidir. Bireyin, kendi kişiliği ile ters düşen bir meslek seçmesi, onun hem mesleki hem de özel yaşantısında ki başarı ve mutluluğunu engeller.

Kişinin mesleğinin onun bedensel, duygusal ve kişisel özelliklerine uygun olması, mesleği yönelik uzun ve yorucu eğitim için de önemlidir. Kişi kendisi ile ilgili önemli dönüm noktalarından biri olan meslek tercihini ergenlik döneminde gerçekleştirir. Şöyle ki, ülkemizde 10. sınıftan itibaren (1314 yaşlar) lise ve seçmeli derslerin seçilmesi, bunu takiben üniversite bölümünün belirlenmesi ile mesleğe doğru adım adım yaklaşılır. Ergenlik döneminin kendine özel çalkantılı dünyasında, hemen hemen her konuda olduğu gibi meslek seçiminde de sağlıklı bir seçim yapmak oldukça zordur. Bu durumda, genci doğru bir tercih için yönlendirme görev ve sorumluluğu; aile, öğretmen, akraba gibi yakın sosyal çevreye düşmektedir. $\mathrm{Bu}$ yönlendirmenin gencin ilgi, yetenek ve kişilik özelliklerini dikkate alınarak yapılması gerekir.

Mesleki gelişim kuramına göre (Ginzberg vd.,1951), meslek seçimi bir anda gerçekleşen bir olay değildir, bilakis çocukluktan yetişkinliğe kadar uzanan dönemi kapsayan bir gelişim sürecini kapsar. Holland'a (1973) göre kendi ilgi ve yeteneklerini tanıyan bireyler, aktif bir biçimde kendilerine en uygun mesleği arayacaktır. Mesleki gelişim ile kişilik dinamiği ile mesleklerin yaratıldığı çevre veya mesleklerin gerektirdiği faaliyetler arasında ilişki vardır. Şöyle ki, altı tip kişilik ve altı tip meslek vardır ve meslek seçimi kişiliğin bir tür yansımasıdır. Roe'nun (1957: 212) kuramına göre, meslek seçimi, yaşamın erken dönemlerinde oluşan ihtiyaçlarla ortaya çıkan bir olgudur. Ona göre, sevilme ihtiyacı yeterince karşılanmamış veya koşula bağlanmış kimseler, ileride insanlarla etkileşimde bulunmayı gerektirmeyen mesleklere yönelmektedir. Kuramın bir diğer önemli ismi Super'e (1957) göre, meslek seçimi bireyin kendini algılama biçiminin, bir başka deyişle benlik algısının bir ifadesidir.

Kişinin seçtiği meslekteki başarısının, üretkenliğinin ve veriminin o toplumun gelişim hızına etkilemesi bu seçimin sadece birey değil, aynı zamanda toplum açısından da önemli olduğunun bir göstergesidir. Dolayısıyla meslek seçimi bireyi ilgilendirdiği gibi kamu politikaları açısından devletleri de ilgilendiren bir konudur. Mesleklerin nitelik ve nicelik yönünden arttı̆̆ ihtiyaç haline gelir. Dolayısıyla mesleğe yöneltme ile ülkelerin eğitim sistemleri arasında sıkı bir ilişki vardır. Gelişmiş sanayi ülkelerinde mesleğe yöneltme görevini resmi kurumlar üstlenmiştir. Bu yüzden kişinin mesleğe yönelik eğitim ve formasyon veren sistemi çok iyi bilmesi, ona göre hareket etmesi gerekir.

Günümüzde hedeflenen çoğu mesleki ideallerin yerine getirilmesinde üniversite eğitiminin alınması oldukça önemlidir. Fakat ülkemizde çeşitli sebeplerle hayal ettiği, becerilerine uygun veya kısmen deneyim sahibi olduğu mesleği çeşitli sebepler yüzünden seçemeyip farklı bir bölümde okuyan öğrenci sayısı oldukça fazladır. $\mathrm{Bu}$ durum öğrencinin okul başarısını etkilediği gibi, okulda sonrasında da zevk almadığı mesleği yapmak zorunda bırakmaktadır.

Vurucu'ya (2010) göre, eğitim süreci içinde çoğu öğrenci genellikle ilgi, istek ve yeteneklerinin hangi meslek alanına daha yatkın olduğunu bilmeden, meslekleri tanımadan, aile ve sosyal çevrenin etkisi ile meslek seçimi yapmaktadır. Gerek eğitim sisteminden kaynaklanan eksiklikler, gerekse öğrencilerin bu konuya gereken ilgiyi vermemeleri sonucunda, bölüm seçimi öncesinde ne yapacağını bilemeyen, kararsız öğrencilerle karşılaşılmaktadır. Bu nedenle, kişinin mesleğine yönelik doğru bir karar almasını etkileyen faktörler oldukça önemlidir.

\section{Literatür}

Meslek seçiminde etkili faktörlere yönelik ülkemizde çeşitli çalışmalar yapılmıştır. Bu çalışmaların bir kısmı konuyu makro düzeyde, diğer bir kısmı çeşitli meslek gruplarıyla ilişkili olarak ele almıştır.

Özyürek ve Atıcı (2002) yapmış oldukları araştırmada, üniversite için bölüm seçimi yapan öğrencilerde rehber öğretmenin, aile ve arkadaş çevresinin bunun yanı sıra basında çıkan haberlerin etkili olduğu sonucuna varmışlardır. Alparslan ve Kılcıgil (2005) tarafından beden eğitimi ve spor yüksekokulu öğrencileri üzerinde yapılan araştırmada, meslek seçiminin tesadüfi olmadığı, öğrencilerin mesleğe yönelik olumlu görüşler beslediği için okudukları bölümü tercih ettikleri belirlenmiştir. Kıyak'ın (2006) genel lise öğrencilerinin meslek seçimi yaparken temel aldığ seçimini etkileyen faktörler şu şekilde sıralanmıştır: meslekte iş bulma imkânı, yetenek, ilgi, değerler, kişilik özellikleri (kendini tanıma), mesleğin getirileri (para, saygınlık, şöhret vb.) ve ailenin isteği şeklindedir. Anılan vd. (2008) ortaöğretim öğrencilerinin üniversite tercihlerine ilişkin anket sonuçlarına göre, öğrenciler meslek seçimi ve üniversite tercihi konusunda kendilerini yeterince bilgili görmemektedirler. Aynı zamanda, öğrencilerin yerleşim yeri unsurunun meslek seçimi kararlarına herhangi bir etkisinin olmadığı görülmüştür.

Yelken (2008), Sakarya il merkezinde orta öğretim son sınıfa giden öğrencilerin üniversite tercihini etkileyen faktörlerin sosyolojik analizini yaptığı araştırması, meslek tercihlerinin okul türüne, anne-babalarının mesleklerine ve öğrenim durumlarına, ailelerinin aylık ortalama gelirine göre farklılık gösterdiği ortaya koymuştur. Yılmaz vd. (2012) önlisans öğrencileri ile yaptığı anket çalışması, öğrencilerin demografik özelliklerinin meslek seçiminde ayırt edici bir unsur olduğu görülmüştür. Sarıkaya ve Khorshid (2009), Ege Üniversitesi'nde kayıtlı 1000 öğrenciye uyguladıkları anket sonuçlarını frekans analiziyle değerlendirmiş ve öğrencilerin bölüm seçme nedenlerini şu şekilde sıralamışlarıdır; mesleğe ilişkin olumlu görüş $(\% 33,6)$, iş avantajları $(\% 28,2)$, çaresizlik duygusu $(\% 23,5)$, başkalarının önerileri $(\% 14,7)$. Arslan (2002), girişimcilik eğiliminin oluşmasında ve mesleki tercihlerde fiziksel, sosyal ve ekonomik çevrenin etkisini, 182 Haliç Üniversitesi öğrencisi üzerinde araştırmıştır. Araştırma sonuçlarına göre, öğrencilerin meslek seçiminde etkili olan faktörlerin başında kâr elde etme isteği, sonra ise bağımsız çalışma isteği gelmektedir.

Baltacı ve Üngören (2010) tarafından yapılan çalışma, öğrencilerin şuan okudukları bölümü seçmelerinin nedenleri 
olarak üniversite sınavından almıș oldukları puan ve mesleğe olan sevgileri ortaya konmuştur. Benzer nitelikte KorkutOwen vd. (2011) yapmış olduğu çalışmaya göre, öğrenciler sırasıyla, alana duyulan ilgi, alınan puanın o bölüme yetmesi, alanın kişilik özelliklerine uygunluğu ve iş bulma olanağının yüksekliği gibi nedenlerle okudukları bölümü seçmişlerdir.

Erdinç ve Kahraman (2012) tarafından yapılan araştırmada, öğrencilerin büyük çoğunluğunun mesleklerini isteyerek ve severek seçtikleri sonucuna varılmıştır. Erdem ve Kayran (2013) tarafindan turizm eğitimi alan öğrencilerin meslek seçimini etkileyen en önemli faktörün kariyer beklentisi olduğu ve bu faktörü kişisel özelliklerin takip ettiği bulunmuştur. Aile ve çevrenin ise, etkisi en az olan unsurlar olduğu görülmüştür. Ulaş ve Yıldırım (2015), aile, arkadaş ve öğretmenden algılanan destek değişkenlerinin ve bazı demografik niteliklerin lise öğrencilerinin mesleki olgunluk düzeylerini yordayıp yordamadığını incelemiştir. Sonuç olarak aile desteği, cinsiyet, öğretmen desteği ve arkadaş desteği değişkenlerinin mesleki olgunluğu manidar olarak yordamakta; sınıf düzeyi ve okul türü değişkenlerinin ise yordamamakta olduğu sonucunu elde edilmiştir. Buna ek olarak kız öğrencilerin mesleki olgunluk düzeylerinin, erkek öğrencilere kıyasla daha yüksek olduğu bulunmuştur.

Aydemir'in (2017) lise öğrencilerinin alan tercihine bağlı olarak mesleki kararsızlık doğuran durumları cinsiyetler arası karşılaştırmalar ile inceleyen çalışmasında, öğrencilerin cinsiyetlerine göre mesleki karar düzeyleri arasında anlamlı bir ilişki olduğu, kendini yeterince tanımama, meslek ve alan bilgisi eksikliği ve meslek seçimine ilişkin akılcı olmayan inanç puanları arasında cinsiyetlere göre anlamlı bir farklılık söz konusu iken, içsel çatışma, dışsal çatışma ve toplam puanlarında bir farklılık görülmediği ortaya konmuştur. Diğer yandan k1z öğrencilerin kendini yeterince tanımama, meslek/alan bilgisi eksikliği ve meslek seçimine ilişkin akılcı olmayan inanç puanları erkek öğrencilerin puanlarından anlamlı derecede yüksek olduğu görülmüştür.

Çapan ve Korkut Owen (2017) cinsiyetleri, okulları, sınıfları ve genel not ortalamaları farklı olan orta öğretim öğrencilerinin Uluslararası Standart Eğitim Sınıflamasına göre yönelmeyi düşündükleri eğitim alanlarının değişip değişmediğini ve en çok istenen eğitim alanlarının hangilerinin olduğunu araştırmıştır. Sekiz farklı eğitim alanına bakıldığında, sınıfın beş, cinsiyetin dört, okul türünün üç ve genel not ortalamasının bir eğitim alanını seçmeyi düşünmede fark yarattığ 1 , ayrıca en fazla istenen ilk üç eğitim alanının, mühendislik, üretim ve yapı, sağlık ve sosyal hizmet ile sosyal bilimler iş yönetimi ve hukuk olduğu sonucu bulunmuştur.

Literatürde bölüm seçimi konusunda yapılmış araştırmalar incelendiğinde, işe ilgi duyma, mesleki bilgi ve yeteneğe sahip olma, iş bulma imkânı, iş güvencesi ve kazancı, kariyer imkânı, toplumsal saygınlık, aile ve çevre gibi faktörlerin meslek seçimi üzerinde etkili olduğu görülmektedir. Yapılan çalışmalarda farklı değişken ve kriterlerin dikkate alınması, meslek seçimini çözümü güç bir problem durumuna getirmektedir. $\mathrm{Bu}$ anlamda, öğrencilerin meslek ve kariyerlerini etkileyen faktörlerin önem derecelerinin belirlenmesi üzerine yapılan bu alan araştırmasının literatüre katkı sağlaması beklenmektedir.

\section{Amaç ve Yöntem}

$\mathrm{Bu}$ çalışma Trabzon'da üniversite eğitimi almakta olan öğrencilerinin bölüm seçimi yapmalarında belirleyici rol oynamış faktörleri saptayarak bölüm seçme kriterlerinin tespit edilmesini ve tercihlerini gerçekleştirirken sahip oldukları bilinç düzeylerini değerlendirmeyi amaçlamaktadır. Bu amaçla, kişilerin bireysel özelliklerinin (ilgi, yetenek, hedef), çevresel faktörlerin (aile, öğretmen, arkadaş), mesleğe ilişkin özelliklerin (maddi kazanç, kariyer, sosyal saygı) bölüm seçimine etkisi analiz edilmiştir. Aynı zamanda kişilerin bölüm tercihlerini yaparken ilgili mesleğin olumlu ve olumsuz yönlerine, uzmanlaşma imkânlarına, mesleğe ilişkin bilgiye sahip olup olmadıkları sorusuna ilişkin yanıt aranmış ve öğrencilerin seçtikleri bölümlerden memnuniyet durumları incelenmiştir.

\subsection{Araştırma Modeli ve Çalışma Grubu}

Bu araştırmada betimsel tarama modeli kullanılmıştır. Tarama modelleri, geçmişte ya da halen var olan bir durumu var olduğu şekilde betimlemeyi amaçlayan araştırma yaklaşımlarıdır (Karasar, 2000). Bu sebeple çalışma, konu olan olay, birey ya da nesne, kendi koşulları içinde ve olduğu gibi tanımlanma amacı taşır

Araştırmanın çalışma grubu basit ve rastgele örnekleme yoluyla seçilmiş öğrencilerden oluşmaktadır. 127'si kadın, 177'si erkek toplam 304 üniversite öğrencisinin \%40,8'i (124) Karadeniz Teknik Üniversitesi ve \% 59,2'si (180) Avrasya Üniversitesi’nde öğrenim görmektedir.

\subsection{Veri Toplama Araçları}

Nicel araştırma yöntemlerinden yüz yüze anket tekniğinin kullanılmıştır. Anket formları 5'li likert ölçeğine göre hazırlanan 36 adet ifadeden oluşmaktadır. İlk altı ifade demografik nitelikte olup; diğerleri bireysel ve çevresel faktörleri, mesleğin olumlu ve olumsuz yönlerinin bölüm tercihine etkisini; öğrencilerin bölümden memnuniyetlerini ve mesleğe ilişkin bilgi donanımlarını ölçmeye yöneliktir. Elde edilen veriler IBM SPSS 23.0 Windows sürümü bilgisayar programı yardımıyla analiz edilmiştir. Anketin iç tutarlılık düzeyine göre Cronbach Alfa değerinin 0.85 olduğu görülmüştür.

Değerlendirmelerde bölüm tercihine etki eden bireysel (ilgi, yetenek, hedef ve idealler vb.), çevresel faktörler (aile, öğretmen, yakın sosyal çevre) ve mesleğe ilişkin özellikler (iş bulma ve kariyer imkânı, maddi kazanç, sosyal statü vb.) bağımsız değişkenler olarak ele alınmıştır.

2016/2017 eğitim-öğretim y1lı içerisinde elde edilen verilerin bir değerlendirmesini sunan bu çalışmanın konusu, Trabzon ilinde öğrenim gören üniversite gençleri ve aşağıdaki alt problemler ile sınırlıdır:

(i) Bireysel faktörlerin bölüm tercihine etkisi nedir?

(ii) Sosyal çevrenin bölüm tercihine etkisi nedir?

(iii) Öğrenciler seçtikleri bölüm hakkında ön bilgiye sahip midir?

(iv) Öğrenciler seçtikleri bölümlerden memnun mudur?

(v) Bölüm tercihinde cinsiyete dayalı farklılıklar söz konusu mudur? 
Bölüm tercihinde cinsiyete dayalı farklılıklar aşağıdaki altı hipoteze dayalı olarak incelenmiştir. Hata payı 0.05 olarak kabul edilmiştir.

1. Hipotez: Yeteneğe uygun bir bölüm tercih etmek ile cinsiyet arasında bir ilişki yoktur.

2. Hipotez: $z_{0}$ Ailenin etkisi altında tercih yapma durumu ile cinsiyet arasında bir ilişki yoktur.

3. Hipotez: Kazancı yüksek olan bir meslek tercihinde bulunma durumu ile cinsiyet arasında bir ilişki yoktur.

4. Hipotez: $z_{0}$ Toplumsal saygınlık beklentisine dayalı bölüm tercihi ile cinsiyet arasında bir ilişki yoktur.

5. Hipotez ${ }_{0}$ : Kariyer yapmaya amacına dayalı bölüm tercihi ile cinsiyet arasında bir ilişki yoktur.

6. Hipotez $z_{0}$ : Bölümden duyulan memnuniyet ile cinsiyet arasında bir ilişki yoktur.

\section{Bulgular}

\subsection{Bireysel Unsurların Bölüm Tercihine Etkisi}

Birey mesleki etkinlikleri yoluyla bir şeyler üreterek, yeteneklerini, bilgi ve becerilerini kullanarak hedeflerini gerçekleştirme yolunda ilerler. Bu yolda ilerlerken sağladığı doyum, onun yaşamdan zevk almasına etki eder. İnsan yaşamının üçte birini kapsayan iş hayatının zevk almadan ya da amaçsızca kullanılması kişinin ruh sağlığını tehdit edici problemlere neden olur. Bu tür sıkıntıları doğuran en önemli neden, bireyin mesleği ile kendi bireysel özelliklerinin bağdaşmamasıdır. $\mathrm{Bu}$ yüzden ilgi, yetenek ve hedeflere uygun mesleki tercihlerin yapılması gerekir. Burada kişinin kendisini ve mesleklerin ne tür ve ne düzeyde yetenek gerektirdiğini bilinmesi oldukça önemlidir. Aksi takdirde, mesleğin gerekliliklerini karşılayamayan birey, farklı türden psikolojik ve sosyal problemler ile başa çıkmak zorunda kalacaktır. Çalışmanın bu bölümünde bağımsız değişken olarak ele alınan bireysel unsurlardan yetenek ve hedeflerin bölüm tercihine etkisi incelenmiştir.

\subsubsection{Ilgi ve Yetenek}

Aşağıdaki tablo katılımcıların \%70'lik büyük çoğunluğunun (katıliyorum ve kesinlikle katıliyorum) yeteneklerine uygun meslekleri tercih ettiklerini göstermektedir. Kalan katılımcıların \%19,7'si (katılmıyorum ve kesinlikle katılmıyorum) tercihinde yeteneğinin bir etkisi olmadığını kabul etmiştir. \%9,5'lik kesim ise okuduğu bölüme ilişkin yeteneğe sahip olup olmadığı konusunda kararsızdır.

Tablo 1. İlgi ve Yeteneğin Bölüm Tercihine Etkisi

\begin{tabular}{lccc}
\hline & Frekans & $\%$ & Kümülatif \% \\
\hline Kesinlikle Katılmıyorum & 36 & 11,8 & 11,8 \\
Katılmıorum & 24 & 7,9 & 19,7 \\
Kararsızım & 29 & 9,5 & 29,3 \\
Katıliyorum & 81 & 26,6 & 55,9 \\
Kesinlikle Katıliyorum & 134 & 44,1 & 100,0 \\
Toplam & 304 & 100,0 & \\
\hline
\end{tabular}

İlgi ve yeteneklerine uygun meslek seçmediğini veya kararsız kaldığını belirten öğrencilerin kendilerini iyi tanımadıklarını ve dolayısıyla yeteneklerini iyi bilmediklerini, yeteneklerini iyi bilseler dahi, çevresel baskı sebebiyle o bölümü seçmediklerini öngörmek mümkün. Diğer yandan, bazı alanlarda meslek eğitiminin zorunlu olması, çoğunlukta meslek eğitiminin uzun, zahmetli ve masraflı sayılması, üniversiteye girmeyi başaran her gencin istediği bölümde öğrenim görememesi, yeterli puan alamaması, mesleğin maddi kazancının yetersiz veya iş olanaklarının az olması vb. etmenler gencin arzu ettiği mesleği seçmesini engelleyen etmenlerden sayllabilir.

Hipotez 1: İlgi ve yeteneğe uygun bir bölüm tercih etmek ile cinsiyet arasında bir ilişki olup olmama durumunun incelenmesi.

$\mathrm{H}_{0 \text { : }}$ Yeteneğe uygun bölüm seçimi ile cinsiyet arasında bir ilişki yoktur.

$\mathrm{H}_{1}$ : Yeteneğe uygun bölüm seçimi ile cinsiyet arasında bir ilişki vardır.

Tablo 2. Yeteneğe göre bölüm tercihi yapan öğrencilerin cinsiyete göre dağılımı

\begin{tabular}{lcccccc}
\hline \multicolumn{7}{l}{ Yeteneklerime uygun olduğu için bu bölümü tercih ettim } \\
\hline Crosstab & 1 & 2 & 3 & 4 & 5 & Toplam \\
\hline Kadın & 12 & 10 & 22 & 28 & 55 & 127 \\
Erkek & 18 & 17 & 16 & 46 & 80 & 177 \\
Toplam & 30 & 27 & 38 & 74 & 135 & 304
\end{tabular}

Not: 1: Kesinlikle katılmıyorum; 2: Katılmıyorum; 3: Kararsızım; 4: Katılıyorum; 5: Kesinlikle katılıyorum.

Tablo 3. Yeteneğe uygun bölüm tercih etme ile cinsiyet arasında ilişki durumu

\begin{tabular}{lccc}
\hline Ki-Kare Testleri & Değer & df & $\begin{array}{c}\text { Asymptotic } \\
\text { Significance } \\
(2-s i d e d)\end{array}$ \\
\hline Pearson Ki-Kare & $4,878^{*}$ & 4 &, 300 \\
Likelihood Ratio & 4,813 & 4 &, 307 \\
Linear-by-Linear Association &, 085 & 1 &, 770 \\
N of Valid Cases & 304 & & \\
* 0 hücre (,\% 0) 5'ten daha az beklenmektedir. Beklenen minimum \\
say1 11,28'dir.
\end{tabular}

Tablo 3'te yeteneğe uygun bölüm tercih etmek ile cinsiyet arasında anlamlı bir ilişki olup olmadığı incelenmiştir. KiKare test sonuçlarına göre $\mathrm{p}=0,300$ olarak gerçekleşmiştir. $\mathrm{Bu}$ oranı $\mathrm{p}=0,05$ anlamlılık değeri ile kıyasladığımızda, bulunan p-değerinin anlamlılık derecesinden yüksek $(0,300>0,05)$ olduğu için sıfır hipotezi kabul edilmektedir. Yani bu iki nitelik \%95 güvenle birbirinden bağımsızdır. Buna göre yeteneklerin bölüm tercihine etkisi ile cinsiyet arasında bir ilişki olmadığı görülmekte ve $\mathrm{H}_{0}$ kabul edilmektedir.

\subsubsection{Hedefler}

Anket sonuçlarına göre, katılımcıların $\% 65,5$ 'lik büyük çoğunluğunun (katılıyorum ve kesinlikle katılıyorum) gelecekteki hedeflerine ulaşmaya yönelik meslek seçiminde bulundukları görülüyor. \%15,5'lik kısım okudukları bölümün hedefleri için uygun olup olmadığg konusunda kararsız olduğunu belirtiyor. Bu kararsızlıklarını, kişilerin hedeflerinin henüz netleşmemiş olmaması, hedeflerine seçtikleri meslek üzerinden ulaşıp ulaşamayacaklarından emin olamamaları, mesleki tercihlerini eksik bilgi veya yönlendirmeyle yapmış olmaları vb. etmenlerle açıklamak mümkün. 
Hedeflerine sahip olacağı meslek üzerinden kesinlikle ulaşamayacağını düşünen \%19,1'lik kesimi oluşturan kişilerin varlığ bölümde okumaya devam ettikleri sorusunu akla getiriyor. Bunda aile baskısı, alınan puanın okuduğu bölüm için yeterli gelmesi vb. gibi çok çeşitli etmenler rol oynayabilir.

Tablo 4. Hedeflere Ulaşma Arzusunun Bölüm Tercihine Etkisi

\begin{tabular}{lccc}
\hline & Frekans & $\%$ & Kümülatif \% \\
\hline Kesinlikle Katılmıorum & 32 & 10,5 & 10,5 \\
Katılmıyorum & 26 & 8,6 & 19,1 \\
Kararsızım & 47 & 15,5 & 34,5 \\
Katıliyorum & 52 & 17,1 & 51,6 \\
Kesinlikle Katıliyorum & 147 & 48,4 & 100,0 \\
Toplam & 304 & 100,0 & \\
\hline
\end{tabular}

Yukarıdaki tabloya göre, hedeflerine okuduğu bölümle ulaşıp ulaşamayacağı konusunda kararsız veya kesinlikle ulaşamayacağını bilen öğrencilerin oranı az denemeyecek kadar fazladır $(\% 34,6)$. Genel itibariyle öğrencilerin hedeflerine hizmet etmeyen bölümlerde okumalarının nedenlerinin bilinmesi ve çözüm yollarının üretilmesi gelecek yıllarda iş piyasasında verimliliğin artmasını sağlayacaktır. Aksi takdirde bu durumun birçok ekonomik, toplumsal ve psikolojik sorunu da beraberinde getirmesi muhtemeldir. Örneğin, bölüm kontenjanlarının o alana ilgi ve istek duymayan öğrenciler ile işgal edilmesi, mezun olduktan sonra kişinin bu mesleği yapmaması sonucunda oluşacak işsizlik ve ekonomik sorunlar, kişilerin iş yaşamındaki memnuniyetsizlikleri sonucu oluşan psikolojik ve sosyal kaynaklı sorunlar gibi.

\subsection{Bölüm Tercihini Etkileyen Çevresel Faktörler}

Meslek seçiminde kişinin ilgi ve yeteneğinin yanı sıra çevresel faktörler de büyük önem taşır. Çünkü uygun bir sosyal çevrenin olmaması, çocuğun yeteneğini keşfetmesini, geliştirmesini zor hatta imkânsız kılabilir. Sosyal çevrenin kişiyi yetenekleri doğrultusunda desteklemesi, bilgilendirmesi, rahat ve huzurlu bir ortam sağlaması, öğrencinin tercihini en doğru şekilde yapmasını kolaylaştıracaktır. Çocuğun kendi özelliklerinin farkına varması ancak temel güven duygusuna sahip olması ile mümkün olur. Eksikliğe ve kusurlara karşı hoşgörüsüz çevrelerde yetişen kişi, yalnızca çevreye değil, kendisine karşı da güvensiz ve hoşgörüsüz bir tutum geliştirmektedirler. Bu kişilerin ana-babalarının ve yakın çevrelerinin ilgi ve sevgisinden yoksun kalmamak için kendi ilgi, istek ve eğilimlerini bir kenara bırakıp, başkalarının gözünde üstün, değerli ve saygın olarak görülen mesleklere yöneldikleri görülür. Bu kişilerin sıklıkla, kendilerinden hoşnut olmayan veya oldukları gibi görünmeye cesaret edemeyen bireyler olarak, kendilerine uygun olmayan tercihler yapma ve bunlarda israr etme eğiliminde oldukları söylenebilir.

Bölüm tercihini tamamen kendi kararı ile yaptığını belirten öğrencilerin oranları Tablo 5 te görülmektedir.

Tablo 5'e göre, okuduğu bölümü tamamen kendi kararı ile seçtiğini belirten öğrencilerin oranı \%74,1'dir (katılıyorum ve kesinlikle katılıyorum). Kendi kararı olmadığını kabul eden ögrrencilerde ise bu oran \%15,1 (katılmiyorum ve kesinlikle katılmiyorum) olarak görülmektedir. Kalan \%10,9'luk kesim ise bu kararı tek başına mı, yoksa çevrenin bir etkisi altında mı aldığı konusunda kararsız olduğunu belirtmektedir.

Tablo 5. Tamamen Kendi Kararıyla Bölüm Tercihi Yaptığını Belirten Öğrencilerin Dağılımı

\begin{tabular}{lccc}
\hline & Frekans & $\%$ & Kümülatif \% \\
\hline Kesinlikle Katılmıorum & 32 & 10,5 & 10,5 \\
Katılmıyorum & 14 & 4,6 & 15,1 \\
Kararsızım & 33 & 10,9 & 26,0 \\
Katılıyorum & 71 & 23,4 & 49,3 \\
Kesinlikle Katıliyorum & 154 & 50,7 & 100,0 \\
Toplam & 304 & 100,0 & \\
\hline
\end{tabular}

Tamamen kendi kararı ile bölüm tercihinde bulunduğunu belirten öğrenciler hakkında, ilgi, yetenek, hedeflerinin ve hayat tercihlerinin ve seçimlerinin farkında, özgüvene sahip bireyler olduklarını söylemek mümkün. Bu sonuçtan yola çıkarak, tercihlerini özgürce belirleyen bu kişilerin gelecekte mesleklerine yönelik pişmanlık duygusunu yaşama olasılığının düşük olacağı söylenebilir. Diğer yandan bu kişiler arasında bilinçli ve yönlendirici bir çevresi olmayan ve sadece bir bölüm seçmek zorunda olduğu için bir tercihte bulunmuş ama bunu kabul etmeyen gençlerin olabileceği de unutulmamalidir.

Gençlerin mesleki tercihlerine çevrenin etkisi aile, okul/öğretmen ve arkadaş/akraba ve yakın çevre çerçevesinde değerlendirilmiştir.

\subsubsection{Aile}

Gençler zihinlerinde kendileri ve meslekler ile ilgili kimlikleri gerçekliğe dönüştürebilme konusunda çevresel desteğe ihtiyaç duyarlar. Aile bu anlamda en büyük destekçileri olmak durumundadır.

Tablo 6. Ailenin Bölüm Tercihine Etkisi

\begin{tabular}{lccc}
\hline & Frekans & $\%$ & Kümülatif \% \\
\hline Kesinlikle Katılmıyorum & 59 & 19,4 & 19,4 \\
Katılmıyorum & 68 & 22,4 & 41,8 \\
Kararsızım & 12 & 3,9 & 45,7 \\
Katıllyorum & 85 & 28,0 & 73,7 \\
Kesinlikle Katıliyorum & 80 & 26,3 & 100,0 \\
Toplam & 304 & 100,0 & \\
\hline
\end{tabular}

Bu araştırmanın sonuçlarına göre, bölüm tercihinde ailesinin etkisi oluğunu kabul eden katılımcıların oranı \%54,3'tür (katılıyorum ve kesinlikle katılıyorum). \%41,8'lik kesim ailesinin herhangi bir etkisi olmadığını belirtirken (katılmiyorum ve kesinlikle katılmıyorum), kalan \%3,9'luk kesim böyle bir etkinin olup olmadığı konusunda kararsız görünmektedir. Kesinlikle katılmıyorum cevabını veren $(\% 19,4)$ öğrencilerin bu seçeneği işaretlemelerinde çeşitli faktörler rol oynayabilir. Örneğin, seçeceği bölümden emin olan gencin ailesinin kendi düşüncesini etkilemesine izin vermemesi veya gencin ailesinin yeteri bilgi ve donanıma sahip olmaması sebebiyle onun tercihine müdahale etmemesi veya gencin müsaade ettirmemesi; ailenin gencin tercihine saygı göstererek bir etkide bulunmak istememesi $\mathrm{vb}$.

Hipotez 2: Ailenin etkisiyle tercih yapma ile cinsiyet arasında bir ilişkinin olup olmama durumunun incelenmesi

$\mathrm{H}^{0}$ : Ailenin etkisiyle tercih yapma ile cinsiyet arasında bir ilişki yoktur. 
$\mathrm{H}^{1}$ : Ailenin etkisiyle tercih yapma ile cinsiyet arasinda bir ilişki vardır.

Tablo 7. Bölüm Seçiminde Ailenin Etkisini Kabul Eden Öğrencilerin Cinsiyete Göre Dağılımı

\begin{tabular}{lcccccc}
\hline \multicolumn{7}{c}{ Bu bölümü seçmemde ailemin etkisi olmuştur. } \\
\cline { 1 - 5 } Crosstab & 1 & 2 & 3 & 4 & 5 & Toplam \\
Kadın & 21 & 27 & 3 & 46 & 30 & 127 \\
Erkek & 38 & 41 & 9 & 39 & 50 & 177 \\
Toplam & 59 & 68 & 12 & 85 & 80 & 304
\end{tabular}

Not: 1: Kesinlikle katılmıyorum; 2: Katılmıyorum; 3: Kararsızım; 4: Kat1liyorum; 5: Kesinlikle kat1liyorum.

Tablo 8. Ailenin Etkisiyle Tercih Yapma İle Cinsiyet Arasındaki İlişki Durumu

\begin{tabular}{lccc}
\hline Ki-Kare Testleri & Değer & df & $\begin{array}{c}\text { Asymptotic } \\
\text { Significance } \\
\text { (2-sided) }\end{array}$ \\
\hline Pearson Ki-Kare & $8,360^{*}$ & 4 &, 079 \\
Likelihood Ratio & 8,380 & 4 &, 079 \\
Linear-by-Linear Association &, 896 & 1 &, 344 \\
N of Valid Cases & 304 & & \\
\hline
\end{tabular}

* 0 hücre (,\% 0) 5 'ten daha az beklenmektedir. Beklenen minimum say1 5,01'dir.

Yukarıdaki çapraz tabloda, katılımcıların bölüm tercihlerinde ailenin etkisiyle tercih yapma ile cinsiyet arasında anlamlı bir ilişki olup olmadığı incelenmiştir. KiKare test sonuçlarına göre $\mathrm{p}=0,079$ olarak bulunmuştur. $\mathrm{Bu}$ oran $\mathrm{p}=0,05$ anlamlılık değeri ile kıyasladığında, bulunan $\mathrm{p}$ değerinin anlamlılık derecesinden yüksek $(0,079>0,05)$ olduğu görülmekte ve sıfır hipotezi kabul edilmektedir. Yani bu nitelikler \%95 güvenle birbirinden bağımsızdır. Buna göre cinsiyet ile bölüm tercihinde ailenin etkisi arasında seçiminde memnuniyet arasında bir ilişki olmadığı görülmektedir. Yani katılımcıların bölüm tercihlerinde ailelerinin etkisi onların cinsiyetlerine göre farklılık göstermemektedir.

\subsubsection{Akraba, Arkadaş, Yakın Çevre}

Tablo 9. Akraba, Arkadaş ve Yakın Çevrenin Bölüm Tercihine Etkisinin Dağılımı

\begin{tabular}{lccc}
\hline & Frekans & $\%$ & Kümülatif \% \\
\hline Kesinlikle Katılmıorum & 81 & 26,6 & 26,6 \\
Katılmıyorum & 73 & 24,0 & 50,7 \\
Kararsızım & 27 & 8,9 & 59,5 \\
Katılıyorum & 72 & 23,7 & 83,2 \\
Kesinlikle Katıliyorum & 51 & 16,8 & 100,0 \\
Toplam & 304 & 100,0 & \\
\hline
\end{tabular}

Tablo 9'da katılımcılara bölüm seçiminde arkadaş, akraba ve yakın çevrenin etkisi gösterilmiştir. Katılımcıların \%,40,5'i bu yakın sosyal çevrenin aldıkları kararda etkisi olduğunu kabul etmiştir (katılıyorum ve kesinlikle katılıyorum). Kalan \%50,6'sı böyle bir etkinin olmadığını (katılmıyorum ve kesinlikle katılmıyorum), \%8,9'u kararsız olduğunu ifade etmiştir.

\subsubsection{Okul/Öğretmen}

Öğretmenlerden, öğrencileri en doğru meslek seçiminde bulunabilmeleri için sistemli bir şekilde yönlendirmeleri beklenir. Vakitlerinin büyük bölümünü okulda geçiren çocukların başarılı olduğu derslerin, çalışmaların bir sonucu olarak, öğretmenlerden öğrencileri başarılı oldukları alanları belirlemelerinde etkin ve yönlendirici olmaları gerekir. Hacettepe Üniversitesi'nin 11.000 lise son sınıf öğrencisi üzerinde yapmış olduğu araştırma bu sonucu doğrular niteliktedir. Araștırma üniversite adaylarının meslek tercihi yaparken en çok rehber öğretmenlerine danıştıklarını ve onlardan etkilendiklerini ortaya koymuştur.

Tablo 10. Okul/Öğretmenlerin Bölüm Tercihine Etkisinin Dağılımı

\begin{tabular}{lccc}
\hline & Frekans & $\%$ & Kümülatif \% \\
\hline Kesinlikle Katılmıorum & 99 & 32,6 & 32,6 \\
Katılmıyorum & 53 & 17,4 & 50,0 \\
Kararsızım & 23 & 7,6 & 57,6 \\
Katılıyorum & 74 & 24,3 & 81,9 \\
Kesinlikle Katıliyorum & 55 & 18,1 & 100 \\
Toplam & 304 & 100,0 & \\
\hline
\end{tabular}

$\mathrm{Bu}$ çalışmanın araştırma verilerine göre, öğrencilerin $\% 42,4$ 'ü öğretmenlerinin tavsiyesi ile tercihte bulunduğunu kabul etmektedir (katıliyorum ve kesinlikle katıliyorum). Buna oran, ailesinin etkisini kabul eden öğrencilerin $(\% 54,3)$ oranından \%11,9 daha düşük, akraba ve arkadaş çevresinden etkilendiğini belirten öğrencilerin oranından $(\% 40,5)$ ise yalnızca \%1,9 daha yüksektir. Bu çalışmada okul/öğretmen yönlendirmesinin bölüm tercihine etkisi beklenenin altında görülmektedir. Bu sonucun sebeplerine yönelik, okullarda öğrencilere meslek seçiminde yeterli desteğin verilmemesi veya öğrenciler/velilerin öğretmen desteğine gereken önemi vermemesi vb. hipotezler ortaya konabilir.

\subsection{Mesleğin Olanaklarının Etkisi}

\subsubsection{Maddi Kazanç}

Kişinin mesleği, yeteneklerine uygun olmasının yanısıra maddi beklentilerine cevap verebilir nitelikte olmalıdır. Bir insanın hayatı boyunca aynı mesleği severek yapması için, mesleğin maddi kazancının kişiyi tatmin etmesi önemlidir. Bu tatminkârlık sınırı kişiden kişiye değişmektedir.

Tablo 11. Mesleğin Maddi Kazancının Bölüm Tercihine Etkisinin Öğrencilere Göre Dağıllımı

\begin{tabular}{lccc}
\hline & Frekans & $\%$ & Kümülatif \% \\
\hline Kesinlikle Katılmıyorum & 37 & 12,2 & 12,2 \\
Katılmıyorum & 24 & 7,9 & 20,1 \\
Kararsızım & 36 & 11,8 & 31,9 \\
Katıliyorum & 113 & 37,2 & 69,1 \\
Kesinlikle Katıliyorum & 94 & 30,9 & 100,0 \\
Toplam & 304 & 100,0 & \\
\hline
\end{tabular}

Araştırma katılımcılarına bölüm tercihinde bulunurken maddi kazancı dikkate alıp almadıkları sorulmuş ve \%68,1'lik büyük çoğunluğun (katılıyorum ve kesinlikle katılıyorum) maddi kazancı yüksek bir meslek kazandırdığı için okuduğu bölümü seçtiği görülmüştür. Kalan \%20,1'i (katılmıyorum, kesinlikle katılmıyorum) böyle bir beklentiye sahip olmadığını belirtmiştir. \%11,5'lik kesim ise kararsızdır. Bu sonuç, maddi kazancın kişilerin geleceğe yönelik planlarında belirleyici bir etkiye sahip olduğunu göstermektedir.

Mesleğin maddi kazancını dikkate almayan öğrencilerin, kendi ailelerinin maddi durumunun orta veya iyi seviyede olduğu veya öğrencinin kendisinin ve ailesinin, kişinin her ne şartta olursa olsun kendi ilgi ve yeteneğine uygun mesleği 
yapmasının doğru olduğuna dair bir görüşe sahip olduğu öngörülebilir.

Hipotez 3: Kazanc1 yüksek bir meslek tercih etme durumu ile cinsiyet arasındaki ilişki durumunun incelenmesi

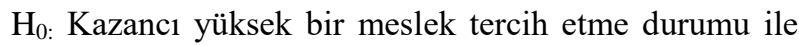
cinsiyet arasında bir ilişki yoktur.

$\mathrm{H}_{1}$ : Kazancı yüksek bir meslek tercih etme durumu ile cinsiyet arasında bir ilişki vardır.

Tablo 12. Mesleğin Maddi Kazancının Bölüm Tercihine Etkisinin Cinsiyete Göre Dağılımı

Kazancı yüksek bir meslek sağlayacağı için bu bölümü tercih ettim.

\begin{tabular}{lcccccc}
\cline { 1 - 5 } Crosstab & 1 & 2 & 3 & 4 & 5 & Toplam \\
\cline { 1 - 3 } & 17 & 8 & 21 & 47 & 34 & 127 \\
Erkek & 20 & 16 & 15 & 66 & 60 & 177 \\
Toplam & 37 & 24 & 36 & 113 & 94 & 304
\end{tabular}

Not: 1: Kesinlikle katılmıyorum; 2: Katılmıyorum; 3: Kararsızım;

4: Katıliyorum; 5: Kesinlikle katıliyorum.

Tablo 13. Kazancı Yüksek Bir Meslek Tercih Etme Durumu İle Cinsiyet Arasındaki İlişki

\begin{tabular}{lccc}
\hline Ki-Kare Testleri & Değer & df & $\begin{array}{c}\text { Asymptotic } \\
\text { Significance } \\
(2-\text {-sided })\end{array}$ \\
\hline Pearson Chi-Square & $6,241^{*}$ & 4 &, 182 \\
Likelihood Ratio & 6,201 & 4 &, 185 \\
Linear-by-Linear Association & 1,087 & 1 &, 297 \\
N of Valid Cases & 304 & & \\
\hline
\end{tabular}

* 0 hücre $(, \%$ 0) 5 'ten daha az beklenmektedir. Beklenen minimum say1 10,03 'dir.

Tablo 13'te katılımcıların kazancı yüksek bir bölüm tercih etmeleri ile cinsiyet arasındaki ilişki incelenmiştir. Ki-Kare test sonuçlarına göre $\mathrm{p}=0,182$ olarak bulunmuştur. Bu oranı $\mathrm{p}=0,05$ anlamlılık değeri ile kıyasladığımızda, bulunan $\mathrm{p}$ değerinin anlamlılık derecesinden yüksek $(0,182>0,05)$ olduğu görülmekte ve sıfır hipotezi kabul edilmektedir. Yani iki nitelik \%95 güvenle birbirinden bağımsızdır. Buna göre kazancı yüksek bir meslek tercih etme ile cinsiyete arasında bir ilişki olmadığı görülmekte ve $\mathrm{H}_{0}$ kabul edilmektedir.

\subsubsection{Toplumsal Saygınlık}

Mesleklerin toplum nezdindeki itibarı toplumsal yapı içinde bireyin yerini belirlemesinin yanı sıra iş piyasalarını, ekonomik yapıyı, eğitim ve istihdam sistemini yakından ilgilendirmektedir. Sunar'ın (2015) “Türkiye Mesleki İtibar Araştırması" mesleklerin itibarları ile kazançları arasındaki yakın bir ilişkiyi ortaya koyan son çalışmalardandır.

Tablo 14. Toplumsal Saygınlığın Bölüm Tercihine Etkisi

\begin{tabular}{lccc}
\hline & Frekans & $\%$ & Kümülatif \% \\
\hline Kesinlikle Katılmıorum & 33 & 10,9 & 10,9 \\
Katılmıyorum & 20 & 6,6 & 17,4 \\
Kararsizım & 37 & 12,2 & 29,6 \\
Katıliyorum & 94 & 30,9 & 60,5 \\
Kesinlikle Katıliyorum & 120 & 39,5 & 100,0 \\
Toplam & 304 & 100,0 & \\
\hline
\end{tabular}

Toplumsal saygınlığı olduğu için okudukları bölümü seçen öğrencilerin oranlarına bakıldığında bu oran katılımcıların \%70,4'üne (katılıyorum ve kesinlikle katılıyorum) tekabül etmektedir. Kalan \%17,4'lük kesim mesleki saygınlığın bölüm tercihlerini etkilemediğini belirtirken (katılmıyorum ve kesinlikle katılmıyorum), \%12,2'lik kesimin kararsız olduğu görülmektedir. $\mathrm{Bu}$ oranlar, mesleğin getirdiği toplumsal saygınlığın, gençlerin geleceğe yönelik planlarında oldukça önemli olduğuna dikkat çekiyor, öyle ki mesleğin sunduğu sosyal statü $(70,4)$ mesleğin sunduğu maddi imkâna $(68,1)$ göre bölüm tercihlerinde daha belirleyici özelliğe sahip görünmektedir.

Hipotez 4: Bölüm tercihinde toplumsak saygınlık beklentisi ile cinsiyet arasındaki ilişkinin incelenmesi

$\mathrm{H}_{0 \text { : }}$ Toplumsal saygınlığın bölüm tercihine etkisi ile cinsiyet arasında bir ilişki yoktur.

$\mathrm{H}_{1}$ : Toplumsal saygınlığın bölüm tercihine etkisi ile cinsiyet arasında bir ilişki vardır.

Tablo 15. Toplumsal Saygınlığın Bölüm Tercihine Etkisinin Cinsiyete Göre Dağılımı

\begin{tabular}{lcccccc}
\hline \multicolumn{6}{c}{ Toplumda saygınlı̆̆ olan bir meslek için bu bölümü tercih ettim. } \\
\hline Crosstab & 1 & 2 & 3 & 4 & 5 & Toplam \\
\hline Kadın & 12 & 7 & 12 & 42 & 54 & 127 \\
Erkek & 21 & 13 & 25 & 52 & 66 & 177 \\
Toplam & 33 & 20 & 37 & 94 & 120 & 304
\end{tabular}

Not: 1: Kesinlikle katılmıyorum; 2: Katılmıyorum; 3: Kararsızım; 4: Katılıyorum; 5: Kesinlikle katıliyorum.

Tablo 16. Toplumsal Saygınlığın Bölüm Tercihine Etkisi İle Cinsiyet Arasında Bir İlişki

\begin{tabular}{lccc}
\hline Ki-Kare Testleri & Değer & $\begin{array}{c}\text { Asymptotic } \\
\text { df }\end{array}$ & $\begin{array}{c}\text { Significance } \\
\text { (2-sided) }\end{array}$ \\
\hline Pearson Ki-Kare & $2,942 *$ & 4 &, 568 \\
Likelihood Ratio & 2,987 & 4 &, 560 \\
Linear-by-Linear Association & 1,854 & 1 &, 173 \\
N of Valid Cases & 304 & & \\
$* 0$ hücre (,\% 0) 5'ten daha az beklenmektedir. Beklenen minimum \\
say1 8,36'dir.
\end{tabular}

Tablo 16'daki Ki-Kare test sonuçlarına göre $\mathrm{p}=0,568$ olarak bulunmuştur. $\mathrm{Bu}$ oranı $\mathrm{p}=0,05$ anlamlılık değeri ile kıyasladığımızda, gerçekleşen p-değerinin anlamlılık derecesinden yüksek $(0,568>0,05)$ olduğu görülmektedir. Yani bu nitelikler birbirinden bağımsızdır. Buna göre cinsiyet ile bölüm seçiminde toplumsal saygınlı̆̆ın etkisi arasında anlamlı bir ilişki söz konusu değildir ve $\mathrm{H}_{0}$ hipotezi kabul edilmektedir.

\subsubsection{Mesleğin Gelecekteki Önemi}

Tablo 17'de katılımcılara edinecekleri mesleklerin gelecekteki öneminin bölüm tercihlerine etkisi sorulmuştur. Elde edilen verilere göre, katılımcıların \%82,3'lük büyük çoğunluğunun (katılıyorum ve kesinlikle katılıyorum) tercihlerine, mesleğin geleceğinin etki ettiği görülmektedir. Kalan 12,5'lik (katılmıyorum ve kesinlikle katılmıyorum) kesim için, bunun pek bir önemi görülmezsen \%5,3'lük kesim ise kararsızdır. $\mathrm{Bu}$ bilgiler doğrultusunda katılımcıların büyük çoğunluğu, tercih ettikleri mesleklerin, gelecekte önem ve geçerliliğini koruyacağını düşünmektedir. 
Tablo 17. Mesleğin Gelecekteki Öneminin Etkisi

\begin{tabular}{lccc}
\hline & Frekans & $\%$ & Kümülatif \% \\
\hline Kesinlikle Katılmıyorum & 27 & 8,9 & 8,9 \\
Katılmıyorum & 11 & 3,6 & 12,5 \\
Kararsızım & 16 & 5,3 & 17,8 \\
Katıliyorum & 110 & 36,2 & 53,9 \\
Kesinlikle Katıliyorum & 140 & 46,1 & 100,0 \\
Toplam & 304 & 100,0 & \\
\hline
\end{tabular}

\subsubsection{Kariyer İmkânının Bölüm Tercihine Etkisi}

Tablo 18, katılımcıların bölüm tercihlerinde mesleki kariyerin etkisini göstermektedir. Buna göre, katılımcıların büyük çoğunluğunu temsil eden 68,7'lik kısım (katıllyorum ve kesinlikle katılıyorum) sahip olacakları meslekte kariyer yapmayı planlamaktadır. Bu kişilerin, okudukları bölümü kendi ilgi ve yeteneklerine dayalı seçmiş oldukları düşüncesinden yola çıkarak ve kazandıkları meslekten farklı iş alanlarına kaymayacakları öngörülebilir.

Tablo 18. Mesleki Kariyer İmkânının Bölüm Tercihine Etkisi

\begin{tabular}{lccc}
\hline & Frekans & $\%$ & Kümülatif \% \\
\hline Kesinlikle Katılmıyorum & 13 & 4,3 & 4,3 \\
Katılmıyorum & 44 & 14,5 & 18,8 \\
Kararsızım & 38 & 12,5 & 31,3 \\
Katıliyorum & 101 & 33,2 & 64,5 \\
Kesinlikle Katıliyorum & 108 & 35,5 & 100,0 \\
Toplam & 304 & 100,0 & \\
\hline
\end{tabular}

Katılımcıların \%18,8'i bu meslekte kariyer yapmak istemiyor (katılmiyorum ve kesinlikle katılmiyorum), $\% 12,5$ 'i ise kararsız olduğunu belirtiyor. Bu kişilerin kariyer yapmak istememelerinin veya kararsız olmalarının çeşitli nedenleri olabilir. Örneğin, kişilerin o işte kariyer imkânlarına yönelik yeterli bilgiye sahip olmamaları, o mesleği isteyerek seçmemiş olmamaları, kendilerine yeterince güvenmemeleri, maddi olanaklarının el vermemesi vb. etmenler sayılabilir.

Hipotez 5: Kariyer yapma düşüncesine dayalı tercihte bulunma ile cinsiyet arasında bir ilişki olup olmama durumunun incelenmesi

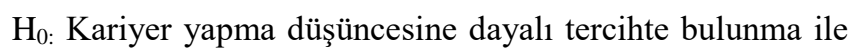
cinsiyet arasında bir ilişki yoktur.

$\mathrm{H}_{1}$ : Kariyer yapma düşüncesine dayalı tercihte bulunma ile cinsiyet arasında bir ilişki vardır.

Tablo 19. Kariyer Yapma Düşüncesine Dayalı Tercihte Bulunma Durumunun Cinsiyete Göre Dağılımı

\begin{tabular}{lcccccc}
\hline \multicolumn{7}{l}{ Kariyer yapabileceğime inandığım için bu bölümü seçtim. } \\
\hline Crosstab & 1 & 2 & 3 & 4 & 5 & Toplam \\
\hline Kadın & 6 & 9 & 23 & 37 & 52 & 127 \\
Erkek & 7 & 35 & 15 & 64 & 56 & 177 \\
Toplam & 13 & 44 & 38 & 101 & 108 & 304
\end{tabular}

Not: 1: Kesinlikle katılmıyorum; 2: Katılmıyorum; 3: Kararsızım;

4: Katıliyorum; 5: Kesinlikle katıliyorum.

Tablo 20'de kariyer yapma düşüncesine dayalı tercihte bulunma ile cinsiyet arasında bir ilişki olduğu görülmektedir. $\mathrm{Ki}-$ Kare test sonuçlarına göre $\mathrm{p}=0,002$ olarak bulunmuştur. $\mathrm{Bu}$ oranı $\mathrm{p}=0,05$ anlamlılık değeri ile kıyasladığımızda, bulunan p-değerinin anlamlılık derecesinden küçük $(0,002<0,05)$ olduğu görülmekte ve sifir hipotezi reddedilmektedir. Yani bu nitelikler \%95 güvenle birbirinden bağımsız değildir. Buna göre kariyer ile cinsiyet arasında anlamlı bir ilișki söz konusudur ve $\mathrm{H}_{1}$ hipotezi kabul edilmektedir.

Tablo 20. Kariyer Yapma Düşüncesine Dayalı Tercihte Bulunma İle Cinsiyet Arasındaki İlişki

\begin{tabular}{lccc}
\hline Ki-Kare Testleri & Değer & df & $\begin{array}{c}\text { Asymptotic } \\
\text { Significance } \\
(2-s i d e d)\end{array}$ \\
\hline Pearson Ki-Kare & $16,719^{*}$ & 4 &, 002 \\
Likelihood Ratio & 17,380 & 4 &, 002 \\
Linear-by-Linear Association & 2,704 & 1 &, 100 \\
N of Valid Cases & 304 & & \\
* 0 hücre (,\% 0) 5'ten daha az beklenmektedir. Beklenen minimum \\
say1 5,43'dir.
\end{tabular}

\subsection{Mesleğe İlişkin Ön Bilgi}

Enerjisini, sevdiği ve doyum sağlayabileceği bir meslek alanında kullanan kişi başarılı bir kariyer elde etme olanağına sahip olur. Bu yüzden, rastgele seçim yapmaktan kaçınmak, edinilecek mesleğin özelliklerini, gerekliliklerini, kariyer imkânlarını araştırmak ve kişisel özellikler ile mesleğin uyumunu değerlendirmek iyi bir kariyer için öngörülen önemli noktalardır. Bunun dışında kulaktan dolma bilgilerle hareket etmek yerine, meslek hakkında edinilen bilgiler 1şı̆̆ında içinde bulunulan toplum ve çalışma hayatında karşılaşabilecek muhtemel durumlar iyisiyle ve kötüsüyle göz önünde bulundurulmalıdır.

$\mathrm{Bu}$ araştırmada öğrencilere okudukları mesleklerin avantaj ve dezavantajlarına, kariyer imkânlarına ve uzman deneyimlerine ait bilgi edinip edinmedikleri sorulmuştur.

\subsubsection{Mesleğin Kolaylık ve Zorluklarına İlişkin Ön Bilgi}

Katılımcıların büyük çoğunluğunu temsil eden \%74'lük kesimin (katılıyorum ve kesinlikle katılıyorum) mesleğin kolaylık ve zorluklarına ilişkin ön bilgi sahibi olduğu görülmektedir. Kalan \%15'lik kısım bu konuda bilgi sahibi olmadığını belirtirken (katılmıyorum ve kesinlikle katılmıyorum), diğer \%10,2'lik k1sım ise net cevap verememiş ve kararsız olduğunu belirtmiştir. $\mathrm{Bu}$ sonuçlar doğrultusunda, katılımcıların büyük çoğunluğunun tercih ettikleri bölümlerin avantaj ve dezavantajlarına ilişkin bilgi edinerek bilinçli bir tercih yapmış olduklarını ve aynı zamanda kazanacakları mesleğe yönelik belirli bir motivasyona sahip olduklarını söylemek mümkün.

Tablo 21. Mesleğin Kolaylık Ve Zorluklarına İlişkin Bilgilenme Durumu

\begin{tabular}{lccc}
\hline & Frekans & $\%$ & Kümülatif \% \\
\hline Kesinlikle Katılmıyorum & 11 & 3,6 & 3,6 \\
Katılmıyorum & 37 & 12,2 & 15,8 \\
Kararsizım & 31 & 10,2 & 26,0 \\
Katıliyorum & 110 & 36,2 & 62,2 \\
Kesinlikle Katıliyorum & 115 & 37,8 & 100,0 \\
Toplam & 304 & 100,0 & \\
\hline
\end{tabular}

\subsubsection{Kariyer Imkânları Hakkında Bilgi}

Tablo 22'de, öğrencilerin \%88,1'lik büyük çoğunluğunun (katılıyorum ve kesinlikle katılıyorum) sahip olacakları meslekte uzmanlaşma imkânları konusunda bilgi sahibi oldukları görülmektedir. Kalan \%8,6’lık kısım kararsız 
olduğunu belirtirken, diğer \%3,3'lük kısım (katılmıyorum ve kesinlikle katılmıyorum) bu konuda bilgiye sahip olmadığını ifade etmiştir.

Tablo 22. Mesleğin Kariyer İmkânlarına İlişkin Bilgiye Sahibim

\begin{tabular}{lccc}
\hline & Frekans & $\%$ & Kümülatif \% \\
\hline Kesinlikle Katılmıyorum & 4 & 1,3 & 1,3 \\
Katılmıyorum & 6 & 2,0 & 3,3 \\
Kararsızım & 26 & 8,6 & 11,8 \\
Katıliyorum & 136 & 44,7 & 56,6 \\
Kesinlikle Katıliyorum & 132 & 43,4 & 100,0 \\
Toplam & 304 & 100,0 & \\
\hline
\end{tabular}

Kariyer imkânlarına ilişkin bilgi edinen öğrencilerin (\%88,1) bu meslekte geleceğe yönelik kariyer hedeflerinin varlığından söz edebiliriz. Meslekte uzmanlaşma şartlarının kişilerce bilinmesi onların hedeflerine ulaşmalarını kolaylaştırıcı bir etkiye sahip olmaktadır.

\subsubsection{Meslek Uzmanlarının Deneyimleri Hakkında Bilgi}

Bölümlerini seçmeden önce mesleğin uzmanlarından deneyimleri hakkında bilgi alıp almadıklarına yönelik katılımcıların büyük çoğunluğu, (katılıyorum ve kesinlikle katıliyorum: \%59,5) uzmanların deneyimlerinden faydalandığını ifade etmiştir. \%32,9'luk (katılmıyorum ve kesinlikle katılmıyorum) kesim bu yolda bir bilgi sağlama yoluna gitmez iken, \%7,6'l1k kesim kararsız olduğunu ifade etmiştir. Kendisini başkalarının deneyimleri üzerinden bilgilendiren \%59,5'lik kesimin meslek ile ilgili yüksek motivasyona sahip olduğu ve meslek hakkında sadece genel geçer bilgilerle yetinmeyip mesleğin püf noktalarını kazanma yoluna gittiği görülmektedir.

Tablo 23. Mesleğin Uzmanlarından Meslek Hakkında Bilgi Kazanımı

\begin{tabular}{lccc}
\hline & Frekans & $\%$ & Kümülatif \% \\
\hline Kesinlikle Katılmıorum & 35 & 11,5 & 11,5 \\
Katılmıyorum & 65 & 21,4 & 32,9 \\
Kararsızım & 23 & 7,6 & 40,5 \\
Kat1liyorum & 87 & 28,6 & 69,1 \\
Kesinlikle Katılıyorum & 94 & 30,9 & 100,0 \\
Toplam & 304 & 100,0 & \\
\hline
\end{tabular}

\subsection{Bölümden Duyulan Memnuniyet}

Katılımcılara bölümlerinden memnun olup olmadıkları sorulduğunda, \% 73,7'lik büyük çoğunluğun (katılmıyorum ve kesinlikle katılmıyorum) okuduğu bölümden memnun olduğunu belirtmiştir. Kalan \%17,5'lik (katılıyorum ve kesinlikle katılıyorum) kesim bölümünden memnun değil iken, \%10,9’luk kesim kararsıdır.

Tablo 24. Bölüm Tercihinden Duyulan Memnuniyet

\begin{tabular}{lccc}
\hline & Frekans & $\%$ & Kümülatif \% \\
\hline Kesinlikle Katılmıyorum & 134 & 44,1 & 44,1 \\
Katılmiyorum & 84 & 27,6 & 71,7 \\
Kararsizım & 33 & 10,9 & 82,6 \\
Kat1liyorum & 27 & 8,9 & 91,4 \\
Kesinlikle Katıliyorum & 26 & 8,6 & 100,0 \\
Toplam & 304 & 100,0 & \\
\hline
\end{tabular}

Hipotez 6: Bölüm tercihinden duyulan memnuniyet ile cinsiyetleri arasında bir ilişki olup olmama durumunun incelenmesi
$\mathrm{H}_{0 \text { : }}$ Bölüm tercihinden duyulan memnuniyet ile cinsiyet arasında bir ilişki yoktur.

$\mathrm{H}_{1}$ : Bölüm tercihinden duyulan memnuniyet ile cinsiyet arasında bir ilişki vardır.

Tablo 25. Bölüm Tercihinden Duyulan Memnuniyetin Cinsiyete Göre Dağılımı

\begin{tabular}{lcccccc}
\hline \multicolumn{2}{l}{ Bölümümden memnunum. } & & & & & \\
\hline Crosstab & 1 & 2 & 3 & 4 & 5 & Toplam \\
\hline Kadın & 9 & 5 & 25 & 29 & 59 & 127 \\
Erkek & 9 & 7 & 32 & 46 & 83 & 177 \\
Toplam & 18 & 12 & 57 & 75 & 142 & 304 \\
\hline
\end{tabular}

Not: 1: Kesinlikle katılmıyorum; 2: Katılmıyorum; 3: Kararsızım;

4: Katıliyorum; 5: Kesinlikle katıliyorum.

Tablo 26. Bölüm Tercihinden Duyulan Memnuniyet İle Cinsiyet Arasındaki İlişki

\begin{tabular}{|c|c|c|c|}
\hline Ki-Kare Testleri & Değer & $\mathrm{df}$ & $\begin{array}{l}\text { Asymptotic } \\
\text { Significance } \\
\text { (2-sided) }\end{array}$ \\
\hline Pearson Ki-Kare & ,903* & 4 & ,924 \\
\hline Likelihood Ratio & ,898 & 4 & ,925 \\
\hline Linear-by-Linear Association &, 352 & 1 &, 553 \\
\hline $\mathrm{N}$ of Valid Cases & 304 & & \\
\hline
\end{tabular}

* 0 hücre $(, \%$ 0) 5 'ten daha az beklenmektedir. Beklenen minimum say1 5,01'dir.

Tablo 26'da cinsiyet ile bölüm memnuniyeti arasında bir ilişki olmadığı görülmektedir. Ki-Kare test sonuçlarına göre $p=0,924$ olarak gerçekleşmiştir. Bu oranı $p=0,05$ anlamlılık değeri ile kıyasladığımızda, gerçekleşen p-değerinin anlamlılık derecesinden yüksektir $(0,09>0,05)$ ve sifir hipotezi kabul edilmektedir. Yani bu nitelikler $\% 95$ güvenle birbirinden bağımsızdır. Cinsiyet ile bölüm memnuniyeti arasında bir ilişki olmaması sebebiyle $\mathrm{H}_{0}$ kabul edilmektedir. Düzeltilmiş sapma değerlerine bakıldığında, bölümünden memnun olmayan ve kesinlikle memnun olmayan öğrencilerin değerlerinin 2 den büyük olduğu görülmektedir. Yüzdeliklere bakıldığında; kesinlikle katılmıyorum diyen katılımcıların \%46,2'sinin kadın, \%53,8'inin erkek, katılmıyorum diyen katılımcıların \%20,5'inin kadın ve 79,5'inin erkek olduğu görülmektedir.

\section{Sonuç}

$\mathrm{Bu}$ araştırmaya göre, araştırma verileri yüzdelik olarak değerlendirildiğinde katılımcıların büyük çoğunluğunun kendi kararları ile $(\% 74,1)$ yeteneklerine uygun bölüm $(\% 70)$ tercihinde bulundukları görülür. Ayrıca katılımcıların $\% 65,5$ 'i tercih ettikleri bölümlerin hedeflerine hizmet etmekte olduğunu kabul etmektedir.

Öğrencilerin bölüm seçiminde etki eden unsurların yüzdeliklerine bakıldığında, ilk sırada "mesleğin gelecekteki önemi koruması" (\%82,3) yer almaktadır. Bunu mesleğin kazandırdığ1 toplumsal saygınlığın $(\% 70,4)$, kariyer imkânının $(\% 68,7)$ takip ettiği görülmektedir. Maddi kazancın ise $(\% 68,1)$ diğerlerine oranla en az etkiye sahip olması dikkat çekicidir.

Her ne kadar öğrencilerin büyük çoğunluğu kendi kararıyla bir tercihte bulunmuş olsa da, sosyal çevrenin direk ya da dolaylı etkisi söz konusudur. Şöyle ki bölüm tercihlerine en büyük etki aile $(\% 54,3)$ tarafından, takiben okul/öğretmenler $(\% 42,4)$ ve akraba ve yakın arkadaş çevresi $(\% 40,5)$ tarafından gerçekleşmekledir. 
Katılımcıların büyük çoğunluğunun (\%74) kesimin mesleğin kolaylık ve zorluklarına ilişkin ön araştırma yaparak bilgi edinmesi ve $(\% 59,5)$ meslek hakkında yapmış oldukları araştırmalarda bu mesleğin uzmanlarıyla görüşüp deneyimlerinden faydalanma yoluna gitmeleri, bilinçli bir tercih için çaba sarf ettiklerini göstermektedir. Bu sonuçlar yukarıdaki verileri doğrular nitelikte öğrencilerin büyük çoğunluğunun yeteneklerine, hedeflerine en uygun mesleği seçmek için gayret ettiği bölüm tercihlerini tesadüfi olarak değil, bilinçli olarak seçtiğini göstermektedir. Katılımcıların büyük çoğunluğunun $(\% 73,7)$ bölümünden memnun olduğunu ifade etmesi bu sonucu doğrular niteliktedir.

Araştırmada öğrencilerin bölüm tercihinde yeteneklerin, ailenin, maddi kazancın, toplumsal saygınlığın, kariyer imkânının etkisi, bölümden memnuniyet durumu ile cinsiyet arasında bir ilişki olup olmadığını ortaya çıkarmak amacıyla altı adet hipotez etüt edilmiştir. Yapılan çapraz tablolar yardımıyla cinsiyet ile kariyer yapma imkânı arasında anlamlı bir ilişki olduğu görülmüştür. Diğer nitelikler ile yani yetenek, toplumsal saygınlık, mesleğin maddi kazancı, ailenin etkisi ile cinsiyet arasında anlamlı bir ilişkinin olmadığ görülmüştür.

Bölüm tercihi öncesinde ne yapacağını bilmeyen, kararsız öğrencilerin oranı oldukça düşüktür. Dikkat çekici olan nokta ise bilinçli bir tercih yapma için çaba sarf eden gençler üzerinde okul/öğretmen yönlendirmesinin beklenenin altında $(\% 42,4)$ olmasıdır. Oysaki insan hayatında böylesine önemli yeri olan bölüm seçiminin en doğru şekilde yapılabilmesi için profesyonel destek önemlidir. Öğrencilere daha iyi profesyonel destek için kişinin kendisini keşfetmesine yönelik ilkokuldan lise son sınıfa kadar hâkim bir müfredat programı ve ögretmenlerin gerçek iş yaşamının dinamiklerinden ve taleplerinden uzak olmayan bir eğitim anlayışı önemlidir.

Araştırma sonuçlara ilişkin ileri sürülen öngörülerin, yapılacak yeni araştırmalarca test edilmesinin konunun daha iyi anlaşılmasına ve literatüre katkı sağlayacağı düşünülmektedir.

\section{Kaynakça}

Alparslan, T., \& Kilcıgil, E., (2005). Ankara Üniversitesi Beden Eğitimi ve Spor Yüksekokulu Öğrencilerinin Sosyo Kültürel Yap1 - Meslek Seçimi İlişkisi. Spormetre Beden Eğitimi ve Spor Bilimleri Dergisi, 3(1), 17-26.

Anılan, H., Çemrek, F., \& Anagün, Ş.S. (2008). Ortaöğretim Öğrencilerinin Meslek Seçimi ve Üniversite Tercihlerine İlişkin Görüşleri (Eskişehir Örneği). E-Journal of New World Sciences Academy Social Sciences, 3(2), 238-249.

Arslan, K. (2002). Üniversiteli Gençlerde Mesleki Tercihler ve Girişimcilik Eğilimleri, Doğuş Üniversitesi Dergisi, 6, $1-11$.

Australian Education Council (1992), Career Education in Australian Schools: National Goals, Student, School and System Outcomes and Evaluative Arrangements. Canberra, Australia.

Aydemir, L. (2017), Lise Öğrencilerinin Meslek Seçimindeki Kararsızlıklarına Etki Eden Faktörler (Trabzon Örneği). Siirt Üniversitesi Sosyal Bilimler Enstitüsü Dergisi, 10, 651-664.
Baltac1, F., \& Üngören, E. (2010). Turizm Eğitimi Alan Öğrencilerin Ĕ̆itim Memnuniyetlerinin ve Gelecĕge Yönelik Bakış Açılarının Belirlenmesine Yönelik Bir Araştırma. İçinde: 11. Ulusal Turizm Kongresi Bildiriler Kitab1, (s.312-323). Ankara: Detay Yayıncılık.

Çapan, B.E., \& Korkut Owen, F. (2017). Orta Öğretim Öğrencilerinin Yönelmeyi Düşündükleri Eğitim Alanları ve Kariyer Psikolojik Danışmanlığı, Elektronik Sosyal Bilimler Dergisi, 16(61), 551-568.

Erdem, B., \& Kayran, M. (2013), Balıkesir Üniversitesi Turizm Otelciliği ve İşletmecilik Yüksekokulu Öğrencilerinin Meslek Seçimini Etkileyen Faktörler Üzerine Bir Araştırma. Cumhuriyet Üniversitesi İktisadi ve İdari Bilimler Fakültesi Dergisi, 14(1), 81-106.

Erdinç, S. B., \& Kahraman, S. (2012). Turizm Mesleğini Seçme Nedenlerinin Incelenmesi. VI. Lisansüstü Turizm Öğrencileri Araştırma Kongresi (12-15 Nisan) Bildiriler Kitab1, 229-237.

Ginzberg, E., Ginsburg, S. W., Axelrad, S., \& Herma, J. L. (1951). Occupational choice. New York: Columbia University Press.

Holland, J.L. (1973). Making vocational choices: A theory of careers. New Jersey: Prentice-Hall, Inc., Englewood Cliffs.

Karasar, N. (2000). Bilimsel Araştırma Yöntemleri. Ankara: Nobel Yayın Dağıtım.

Kıyak, S. (2006). Genel Lise Öğrencilerinin Meslek Seçimi Yaparken Temel Aldığı Kriterler. Yüksek Lisans Tezi. İstanbul: Yeditepe Üniversitesi.

Korkut Owen, F., Yılmaz, O., Kepir, D., Ulaş, Ö., \& Özdemir, S. (2011). Üniversite Öğrencilerine Bölüm Seçimlerini Etkileyen Etmenler. XI. Ulusal Psikolojik Danışmanlık ve Rehberlik Kongresi. (Erişim: 01.01.2015), http://www.pegem.net/akademi/kongre bildiri_detay.aspx?id=134312

Kuzgun, Y. (2004). Meslek Rehberliği ve Danışmanlığına Giris, Ankara: Nobel Yayın Dağıtım.

Özyürek, R., \& Atıc1, M. (2002). Üniversite Öğrencilerinin Meslek Seçimi Kararlarında Kendilerine Yardım Eden Kaynakların Belirlenmesi. Türk Psikolojik Danışma ve Rehberlik Dergisi, 2(17), 33-42.

Özsoy, O. (2002). Geleceğin Meslekleri. İstanbul: Hayat Yayınları.

Roe, A. (1957). Early Determinants of Vocational Choice. Journal of Counseling Psychology, 4(3), 212-217.

Sarkaya, T., \& Khorshid, L. (2009). Üniversite Öğrencilerinin Meslek Seçİmini Etkileyen Etmenlerin İncelenmesi. Üniversite Öğrencilerinin Meslek Seçimi. Türk Ĕ̆itim Bilimleri Dergisi, 7(2), 393- 423.

Sunar, L. (2015). Türkiye'de Çalışma Yaşamı ve Mesleklerin Itiibarı. (Erişim: 10.11.2017), http://turkeyses.net/meslekiitibar/

Super, D. E. (1957). The Psychology of Careers. New York: Harper. 
Ulaş, Ö., \& Yıldırım, İ. (2015). Lise Öğrencilerinde Mesleki Olgunluğun Yordayıcıları. Hacettepe Üniversitesi Ĕgitim Fakültesi Dergisi, 30(2), 151-165.

Vurucu, F. (2010). Meslek Lisesi Öğrencilerinin Meslek Seçimi Yeterliliği ve Meslek Seçimini Etkileyen Faktörler. Yüksek Lisans Tezi. İstanbul: Yeditepe Üniversitesi.

Yelken, K. (2008). Orta Öğretim Son Sinıf Öğrencilerinin Üniversite Tercihlerini ve Meslek Seçimini Etkileyen Faktörler: Sakarya Il Merkezi Örneği. Yüksek Lisans Tezi. Sakarya: Sakarya Üniversitesi. 